\title{
PENGEMBANGAN MEDIA PEMBELAJARAN TANGGA PINTAR MATERI PENJUMLAHAN DAN PENGURANGAN KELAS I SEKOLAH DASAR
}

\author{
Vera Yuli Erviana dan Muslimah \\ Universitas Ahmad Dahlan \\ e-mail: vera.erviana@pgsd.uad.ac.id
}

\begin{abstract}
Abstrak
Penelitian ini bertujuan untuk mengetahui pengembangan dan kelayakan media Tangga Pintar penjumlahan dan pengurangan Matematika kelas I sekolah dasar. Jenis penelitian ini merupakan penelitian pengembangan dengan model pengembangan ADDIE (Analysis, Design, Development, Implementation, Evaluation). Subjek penelitian adalah ahli media, ahli materi, ahli pembelajaran, guru dan peserta didik. Instrumen penelitian berupa wawancara dan angket. Hasil pengembangan berupa media pembelajaran Tangga Pintar penjumlahan dan pengurangan Matematika kelas I sekolah dasar, berdasarkan hasil penilaian ahli media mendapat nilai 78,12 (baik). Ahli materi mendapat nilai 88,75 (sangat baik). Ahli pembelajaran mendapat nilai 78,94 (baik). Hasil uji coba I dan II, penilaian angket dari guru diperoleh nilai 97,36 (sangat baik). Penilaian angket respon peserta didik uji coba I diperoleh hasil 78,07, uji coba ke II 89,92 dengan rata-rata nilai kedua uji coba tersebut 83,99 (sangat baik) nilai pretest 54,58 dan nilai posttest 84,58 . Sehingga dari hasil tersebut media pembelajaran tangga pintar layak digunakan oleh peserta didik.
\end{abstract}

Kata Kunci: Media Tangga Pintar, Penjumlahan dan Pengurangan, Sekolah Dasar

\section{THE DEVELOPMENT OF TANGGA PINTAR LEARNING MEDIA IN ADDITION AND SUBTRACTION LEARNING MATERIALS OF FIRST GRADE ELEMENTARY SCHOOL}

\begin{abstract}
This research aimed to determine the development and feasibility of tangga pintar (smart ladder) media in Mathematics addition and subtraction learning materials of first grade elementary school. This was development research with the ADDIE development model (Analysis, Design, Development, Implementation, Evaluation). The research subjects were media expert, material expert, learning expert, teachers, and students. The research instruments were interviews and questionnaires. The results of the development were in the form of Tangga Pintar (smart ladder) learning media of Mathematics addition and subtraction of first grade elementary school. The results of the media expert assessment was scored 78,12 (good). The material expert scored 88,75 (very good). Learning expert scored 78,94 (good). For the results of trials I and II, the questionnaire assessment from the teacher obtained a score of 97,36 (very good). The questionnaire of students' responses of the Trial I is 78, 07, while the Trial II is 89,92, thus the average of the two trials is 83,99 (very good). pretest score is 54,58, while the posttest is 84,58. Therefore, from these results, Tangga Pintar (smart ladder) learning media is feasible to be used by students.
\end{abstract}

Keywords: Smart Ladder Media, Addition and Reduction, Elementary School

\section{PENDAHULUAN}

Secara umum dapat diketahui bahwa dunia pendidikan adalah modal dasar dari kemajuan bangsa. Ilmu Pengetahuan dan Teknologi dapat dikembangkan melalui dunia pendidikan. Hal tersebut selaras dengan Undang-undang R.I. Nomor 20 Tahun 2003 Pasal 1 tentang Pendidikan Nasional. Pasal menjelaskan bahwa pendidikan merupakan salah satu usaha 
yang sengaja dirancang oleh pemerintah untuk mengembangkan potensi-potensi dalam diri seseorang. Tujuan dari pengembangan potensi tersebut yaitu untuk menciptakan kepribadian seseorang yang kuat baik secara spiritual, keagamaan, pengendalian diri, kepribadian, kecerdasan, akhlak mulia, serta ketrampilan yang diperlukan dirinya, masyarakat, bangsa dan negara. Sehingga dalam hal ini pendidikan merupakan salah satu hal yang penting dalam terbentuknya suatu negara yang maju.

Matematika merupakan salah satu mata pelajaran yang diberikan dengan maksud untuk meningkatkan dan mempertinggi kualitas atau mutu pengajaran dalam proses belajar mengajar. Mata pelajaran Matematika sebagai salah satu mata pelajaran di Sekolah Dasar (SD) yang mempunyai ciri-ciri khusus antara abstrak, deduktif, konsisten, hirarkis, dan logis. James \& James (Santri, 2016) menyatakan bahwa Matematika merupakan ilmu mengenai logika, bentuk, susunan, besaran, dan konsep-konsep yang berhubungan antara satu dengan lainnya. Tujuan pendidikan Matematika sekolah dasar adalah agar peserta didik terampil menggunakan konsep Matematika dalam kehidupan sehari-hari.

Pada kenyataannya Matematika merupakan salah satu mata pelajaran yang sulit untuk dipahami hanya dalam satu pertemuan. Biasanya dalam satu materi khusus disajikan secara mendalam dan berulang. Pemikiran terhadap sulitnya Matematika juga diungkapkan oleh Yuniawantika (2016) bahwasanya Matematika dianggap sebagai ilmu yang ditakuti, menyeramkan, dan membosankan bagi siswa, bahkan terdapat orang yang phobia terhadap pembelajaran Matematika. Adanya persepsi tersebut yang dirasakan sebagian peserta didik akan menghambat jalannya proses pembelajaran Matematika itu sendiri. Pada umumnya setiap peserta didik mempunyai karakteristik yang berbeda-beda.

Menurut Piaget (Heruman, 2010), peserta didik sekolah dasar masih berada pada masa operasional konkret yaitu kemampuan dalam proses berfikir untuk mengoperasikan kaidah-kaidah logika, meskipun masih terikat dengan objek yang bersifat konkret. Dikarenakan pembelajaran Matematika yang abstrak, peserta didik memerlukan alat bantu berupa media, dan alat peraga yang dapat memperjelas apa yang akan disampaikan oleh guru sehingga lebih cepat dipahami dan dimengerti peserta didik terutama peserta didik kelas bawah. Penggunaan media pembelajaran sangat penting. Hamalik (Arsyad, 2015) menyatakan pemakaian media pembelajaran dalam proses belajar mengajar dapat membangkitkan keinginan dan minat baru, membangkitkan motivasi dan merangsang kegiatan belajar, dan bahkan membawa pengaruh-pengaruh psikologi terhadap peserta didik. Media yang dirancang dengan baik akan sangat membantu peserta didik mencapai tujuan pembelajaran (Nurseto, 2011).

Berdasarkan hasil observasi di SD Muhammadiyah Mantaran, pada tanggal 27 September sampai 3 Oktober 2017, dapat dilihat bahwa peserta didik masih kesulitan memahami materi penjumlahan dan pengurangan pada semester satu. Belum sepenuhnya memahami simbol angka yang berdampak pada belum lancarnya peserta didik dalam menghitung, serta belum maksimalnya pengembangan media khususnya pada materi penjumlahan dan pengurangan. Media yang digunakan oleh guru sebatas gambar yang ada pada buku pelajaran.

Hal tersebut merupakan masalah bagi pengajar untuk memilih metode ataupun media mengajar yang menarik perhatian siswa dalam belajar sehingga akan menimbulkan minat dan motivasi bagi peserta didik untuk berprestasi yang juga akan mendukung terhadap hasil belajar Matematika. Karena dengan belajar Matematika, kita akan belajar menalar secara kritis, kreatif, dan aktif (Susanto, 2013).

Berdasarkan beberapa hal yang telah dipaparkan di atas, maka akan diadakan penelitian dengan menggunakan media 
Tangga Pintar untuk membantu peserta didik dalam proses pembelajaran khususnya pembelajaran Matematika pada materi penjumlahan dan pengurangan. Media Tangga Pintar merupakan media yang dibuat menyerupai tangga berbentuk 3 dimensi. Jonkenedi (2017) media tiga dimensi merupakan media yang cocok untuk meningkatkan keaktifan siswa karena penyajiannya konkret dan menghindari verbalisme, sehingga peserta didik akan aktif dalam proses pembelajaran. Beberapa materi pada Matematika yang menggunakan bentuk tangga sebagai gambaran medianya yaitu materi konveksi satuan panjang, satuan massa, satuan luas maupun satuan volume.

Sebagai media menghitung, media Tangga Pintar dilengkapi oleh stik bergambar sebagai media menghitungnya. Hal tersebut untuk membuat peserta didik ikut berperan aktif dalam pembelajaran melalui penggunaan media pembelajaran. Penelitian mengenai pengembangan media berbentuk tangga 3 dimensi pernah dilakukan oleh Hayati \& Rahmawati (2017) anak usia sekolah dasar masih dalam masa berpikir operasional konkrit, sehingga membutuhkan media konkret dalam proses belajar mengajar, media pembelajaran berbentuk tiga dimensi dengan penggunaan model permainan telah memenuhi dua karakteristik dari PMRI yaitu siswa berperan aktif dan terdapat media pembelajaran.

Berdasarkan hal tersebut memberikan sebuah terinspirasi untuk mengembangkan media tangga pintar berbentuk tangga tiga dimensi untuk materi penjumlahan dan pengurangan. Media tangga pintar mempunyai inti persamaan pengoperasionalan yang sama dengan penelitian yang pernah dilakukan sebelumnya, menaiki setiap anak tangga berarti menambahkan jumlah dan menuruni setiap anak tangga akan mengurangi jumlah. Dilengkapi gambar-gambar menarik yang disesuaikan dengan materi serta digunakan warna-warna menarik yang sesuai disesuaikan dengan karakteristik siswa kelas rendah.
Berdasarkan identifikasi masalah di atas dapat dirumuskan tujuan penelitian ini sebagai berikut: untuk mengetahui pengembangan dan kelayakan media tangga pintar penjumlahan dan pengurangan Matematika kelas I sekolah dasar.

\section{METODE}

Penelitian ini merupakan jenis penelitian pengembangan media untuk pembelajaran atau Research and Development (R\&D). Merupakan metode penelitian yang digunakan untuk menghasilkan produk tertentu dan menguji keefektifan produk. Penelitian ini mengacu pada model ADDIE, menurut Robert Maribe Branch Sugiyono (2015) merupakan kepanjangan dari Analysis, Design, Development, Implementation, Evaluation.

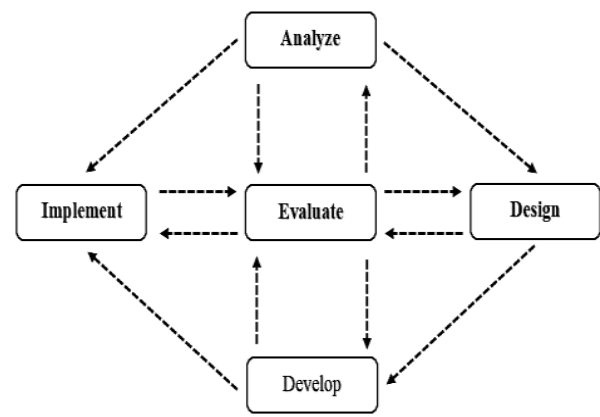

Gambar 1. Langkah-langkah Penelitian dan Pengembangan ADDIE

Prosedur Pengembangan dari penelitian ini meliputi kegiatan analysis, design, development, implementation, dan evaluation. Tahap analysis merupakan tahapan di mana peneliti menganalisis perlunya pengembangan media pembelajaran dan menganalisis kelayakan serta syarat-syarat pengembangan. Terdapat tiga tahapan pada tahap analisis ini yaitu analisis awal (analisis kebutuhan), analisis kurikulum, dam analisis karakter peserta didik.

Tahapan kedua dari model ADDIE adalah tahap design atau perancangan. Setelah melakukan analisis, selanjutnya dilakukan perencanaan untuk membuat desain media pembelajaran tangga pintar penjumlahan dan pengurangan. Pada tahap 
perencanaan, peneliti melakukan beberapa langkah untuk membuat desain materi, desain media pembelajaran tangga pintar, dan desain penggunaan media pembelajaran tangga pintar penjumlahan dan pengurangan.

Kemudian, hasil desain yang telah dibuat divalidasi oleh ahli. Validasi desain dilakukan oleh ahli media. Kemudian, untuk pemilihan materi akan divalidasi oleh ahli materi. Pada bagian alur pembelajaran akan divalidasi oleh ahli pembelajaran. Pada penelitian ini dibuat desain media pembelajaran yang telah dikembangkan yaitu media pembelajaran tangga pintar penjumlahan dan pengurangan.

Langkah ketiga yaitu development, merupakan proses pembuatan media pembelajaran tangga pintar penjumlahan dan pengurangan sesuai dengan langkahlangkah desain yang telah dibuat. Selain itu peneliti melakukan validasi media pembelajaran tangga pintar penjumlahan dan pengurangan. Pada tahap ini juga dilakukan uji coba produk pada ahli dan perbaikan atau revisi produk berdasarkan penilaian dan penelaahan ahli. Ahli yang memvalidasi media pembelajaran tangga pintar penjumlahan dan pengurangan berfungsi untuk mengetahui kualitas media pembelajaran dari segi desain, penampilan, dan layak atau tidak untuk digunakan dalam proses pembelajaran. Selain itu, ahli juga berfungsi sebagai kontrol kualitas media pembelajaran tangga pintar penjumlahan dan pengurangan sebelum diujicobakan dari segi isi atau ketepatan terhadap materi yang akan disampaikan. Hal ini bertujuan sebagai dasar untuk menentukan kelayakan kualitas media pembelajaran tangga pintar penjumlahan dan pengurangan yang dikembangkan sehingga produk media pembelajaran tersebut menjadi produk yang layak.

Tahap Implementation (Implementasi) atau pelaksanaan, akan dilakukan uji coba produk di SD Muhammadiyah Mantaran. Adapun subjek uji coba pada penelitian ini adalah peserta didik kelas I SD Muhammadiyah Mantaran. Tujuan dari uji coba ini untuk memperoleh respon peserta didik terhadap media pembelajaran tangga pintar penjumlahan dan pengurangan. Pada implementasi ini akan dilakukan melalui uji coba produk pada peserta didik, selain itu juga memberikan lembar angket untuk peserta didik bagaimana respon terhadap media pembelajaran tangga pintar penjumlahan dan pengurangan.

Tahap Evaluation (Evaluasi) ini, merupakan tahap mengevaluasi seluruh proses pengembangan produk hingga uji coba produk. Pada tahap ini dilakukan analisis data yang telah diperoleh dari uji coba produk. Tujuannya adalah data yang diperoleh dianalisis untuk diketahui revisi yang perlu dilakukan serta menganalisis apakah produk yang dikembangkan sudah dapat dikatakan praktis dan layak digunakan.

Setelah mengetahui langkah-langkah pengembangannya selanjutnya yaitu tahap uji coba produk. Terdapat beberapa hal yang ada pada tahap uji coba produk memiliki beberapa hal yang perlu diketahui yaitu melalui desain uji coba, subjek coba, dan jenis data. Tahap desain uji coba, pada penelitian ini uji coba produk ditunjukan dengan beberapa langkah sebagai berikut. Membuat desain produk atau produk awal; melaksanakan validasi produk kepada ahli media dan materi; melaksanakan validasi produk kepada praktisi pendidikan/ guru; merevisi produk awal dengan mempertimbangkan masukan dari ahli media, materi dan praktisi pendidikan; melaksanakan uji produk kepada siswa dan membagikan angket untuk memperoleh data tentang produk yang dikembangkan dari siswa; melakukan revisi dengan mempertimbangkan hasil angket yang diberikan kepada siswa; serta hasil akhir meliputi produk pengembangan final.

Subjek uji coba pada penelitian ini adalah peserta didik kelas I SD Muhammadiyah Mantaran yang terdiri 24 peserta didik. Jenis data yang digunakan pada penelitian pengembangan ini terdiri dari dua jenis yaitu data kualitatif dan data kuantitatif. Data kuantitatif berupa saran, masukan, kritik, dan komentar terhadap 
media yang dikembangkan. Data kuantitatif berupa hasil skor dari angket yang disebar. Adapun panduan penskoran tersebut sebagai berikut:

Tabel 1. Pedoman Penyekoran

\begin{tabular}{lc}
\hline \multicolumn{1}{c}{ Keterangan } & Skor \\
\hline Sangat Layak (SL) & 4 \\
Layak (L) & 3 \\
Cukup Layak (CL) & 2 \\
Tidak Layak (TL) & 1 \\
\hline
\end{tabular}

Instrumen pengumpulan data merupakan cara untuk mengumpulkan data. Data yang diperoleh nantinya akan digunakan sebagai hasil dari penilaian media. Lembar observasi yang ditujukan kepada ahli media, ahli materi, ahli pembelajaran, guru kelas, dan respon siswa yang ditujukan dengan anket penilaian. Pengumpulan data berupa Instrumen wawancara dan angket penilaian media.

Teknik analisis data, teknik pengumpulan data diperoleh dari instrumen uji kelayakan ahli media, uji kelayakan ahli materi, uji kelayakan ahli pembelajaran uji untuk respon peserta didik. Skor yang telah diperoleh selanjutnya yaitu menentukan nilai ke dalam rumus menurut Arikunto (2011):

$$
x=\frac{\text { jumlah nilai yang diperoleh }}{\text { jumlah nilai maksimum }} \times 100
$$

Keterangan:

$x=$ persentase kelayakan atau kualitas media

Setelah didapat skor penilaian dari setiap validator, maka mencari rata-rata dengan mnggunakan rumus menurut Arikunto (2011):

$$
X=\frac{\sum x}{N}
$$

Keterangan :

$\sum x=$ jumlah nilai

$\mathrm{X}=$ rata-rata

$\mathrm{N}=$ jumlah penilai
Data kuantitatif yang diperoleh dengan menggunakan rumus di atas kemudian dikonvensikan sebagai berikut menurut Arikunto, (2011).

Tabel 2. Kriteria Penilaian Ideal

\begin{tabular}{lc}
\hline \multicolumn{1}{c}{ Rentang Skor } & Klasifikasi \\
\hline Kualitatif & Sangat Baik \\
Skor antara $81-100$ & Baik \\
Skor antara $61-80$ & Cukup \\
Skor anatar 41 -60 & Kurang Baik \\
Skor antara $21-40$ & Sangat Kurang \\
Skor kurang dari 20 & Baik \\
\hline
\end{tabular}

Berdasarkan kategori perhitungan di atas, dapat diketahui bahwa produk media pembelajaran Tangga Pintar dinyatakan layak jika berada pada skor kelayakan antara 61 - 80 yaitu pada kategori Baik.

\section{HASIL DAN PEMBAHASAN \\ Hasil}

A. Hasil Uji Coba

Data yang diperoleh dari hasil penelitian ini berupa data kualitatif dan data kuantitatif. Data kualitatif berupa komentar atau saran yang diberikan oleh ahli media, ahli materi, ahli pembelajaran, respon peserta didik, dan respon guru.

1. Data Hasil Validasi Ahli Media.

Validasi ahli media terhadap media tangga pintar dilakukan oleh salah satu dosen PGSD UAD yang memiliki kompetensi dalam bidang teknologi pembelajaran. Berdasarkan hasil uji validasi ahli media terhadap media pembelajaran tangga pintar diperoleh jumlah skor 50 dan dihitung menggunakan rumus mendapat nilai 78,12 dengan kriteria "Baik". Adapun rumus menghitung nilai oleh ahli media.

$$
\begin{aligned}
x & =\frac{\text { jumlah nilai yang diperoleh }}{\text { jumlah nilai maksimum }} \times 100 \\
& =\frac{50}{64} \times 100
\end{aligned}
$$




$$
=78,12
$$

Kesimpulan dari hasil validasi media yaitu media tangga pintar penjumlahan pengurangan layak untuk uji coba produk dengan revisi.

\section{Hasil Validasi Ahli Materi}

Validasi ahli materi terhadap media tangga pintar dilakukan oleh salah satu dosen PGSD UAD yang memiliki kompetensi di bidang pembelajaran Matematika sekolah dasar. Berdasarkan hasil validasi ahli materi terhadap media pembelajaran tangga pintar penjumlahan dan pengurangan diperoleh skor yang diperoleh adalah 71. Adapun hasil nilai yang diperoleh 88,75 dengan kriteria "Sangat Baik". Berikut ini merupakan rumus menghitung nilai dari ahli materi.

$$
\begin{aligned}
x & =\frac{\text { jumlah nilai yang diperoleh }}{\text { jumlah nilai maksimum }} \times 100 \\
& =\frac{71}{80} \times 100 \\
& =88,75
\end{aligned}
$$

Kesimpulan dari hasil validasi ahli materi yaitu media pembelajaran tangga pintar layak untuk di uji coba produk melalui tahapan revisi.

3. Hasil Validasi Ahli Pembelajaran.

Validasi ahli pembelajaran dilakukan oleh Ibu Asih Mardati, M.Pd selaku dosen PGSD UAD yang memiliki kompetensi dalam bidang materi Matematika sekolah dasar. Berdasarkan hasil uji validasi ahli pembelajaran terhadap media tangga pintar penjumlahan dan pengurangan diperoleh skor 60. Melalui skor tersebut kemudian diperoleh nilai 78,94 dengan kategori "Baik". Berikut ini merupakan cara pernghitungan nilai hasil uji validasi ahli pembelajaran.

$$
\begin{aligned}
x & =\frac{\text { jumlah nilai yang diperoleh }}{\text { jumlah nilai maksimum }} \times 100 \\
& =\frac{60}{76} \times 100 \\
& =78,94
\end{aligned}
$$

Kesimpulan dari hasil validasi ahli materi yaitu media pembelajaran tangga pintar penjumlahan dan pengurangan layak untuk di uji coba produk dengan melalui tahap revisi.

Tabel 3. Hasil Penilaian Ahli terhadap Media

\begin{tabular}{cccl}
\hline No & Penilai & Nilai & Kategori \\
\hline 1 & Ahli Media & 78,12 & Baik \\
2 & Ahli Materi & 88,75 & Sangat \\
& & & Baik \\
3 & Ahli & 78,94 & Baik \\
& Pembelajaran & & \\
& Jumlah & 245,8 & Sangat \\
& & 1 & Baik \\
\hline & Rata-Rata & 81,93 & Sangat \\
& & & Baik \\
\hline
\end{tabular}

Selain dapat dilihat dalam bentuk tabel, penilaian dari para ahli tersebut juga dilihat dalam bentuk diagram. Berikut merupakan diagram dari hasil penilaian para ahli terhadap media tangga pintar yang dikembangkan.

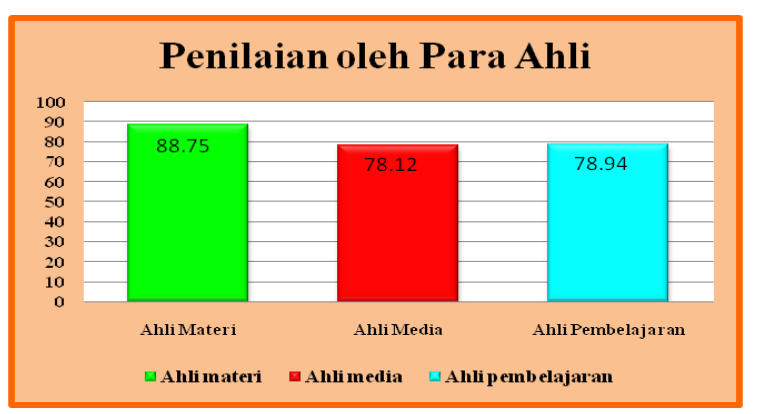

Gambar 2. Diagram Penilaian Para Ahli 
4. Hasil Respon Peserta Didik

a. Perolehan angket respon peserta didik.

Tabel 4. Hasil Angket Respon Peserta Didik

\begin{tabular}{|c|c|c|c|}
\hline No & Penilaian & Nilai & Kategori \\
\hline 1 & $\begin{array}{l}\text { Respon } \\
\text { peserta } \\
\text { didik uji } \\
\text { coba I }\end{array}$ & 78,07 & Baik \\
\hline 2 & $\begin{array}{l}\text { Respon } \\
\text { peserta } \\
\text { didik uji } \\
\text { coba II }\end{array}$ & 89,92 & Sangat Baik \\
\hline & Jumlah & $\begin{array}{c}167,9 \\
9\end{array}$ & Sangat Baik \\
\hline & Rata-Rata & 83,99 & Sangat Baik \\
\hline
\end{tabular}

Selain melalui tabel tersebut, hasil dari penilaiaan respon peserta didik dapat juga dilihat dalam bentuk diagram. Berikut merupakan gambar diagram yang menunjukan hasil dari respon peserta didik.

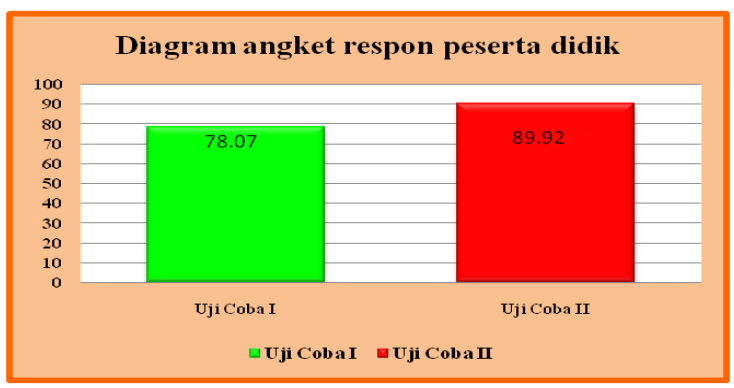

Gambar 3. Diagram Hasil Respon Peserta Didik melalui Angket

Hasil perolehan rata-rata nilai dari peserta didik kelas I pada saat uji coba I yaitu 78, 07 termasuk dalam kategori baik. Pada hasil uji coba II hasil perolehan rata-rata nilai peserta didik diperoleh hasil 89,92 termasuk pada kategori sangat baik. Berdasarkan uji coba produk media pembelajaran tangga pintar layak digunakan dalam proses pembelajaran. Proses menghitung nilai sebagai berikut.

$$
\begin{aligned}
\sum \mathrm{x} & =78,07+89,92 \\
\mathrm{x} & =\frac{\sum x}{n} \\
& =\frac{167,99}{2} \\
& =83,99
\end{aligned}
$$

Hasil perolehan rata-rata nilai dari uji coba I dan uji coba II adalah 83,99 termasuk dalam kategori sangat baik, sehingga digunakan dalam proses pembelajaran.

b. Hasil Pretest dan Posttest

Tabel 5. Data Kuantitatif Pretest dan Posttest

\begin{tabular}{llcc}
\hline No & Penilaian & $\begin{array}{c}\text { Jumlah } \\
\text { Nilai }\end{array}$ & $\begin{array}{c}\text { Rata- } \\
\text { Rata }\end{array}$ \\
\hline 1 & Pretest & 1310 & 54,58 \\
2 & Posttest & 2030 & 84,58 \\
\hline
\end{tabular}

Guna mengetahui perbedaan antara hasil pretest dan posttest yang telah dilaksanakan, maka selain dalam entuk tabel disajikan juga dalam bentuk gambar diagram. Berikut merupakan gambaran dari diagram hasil pretest dan posttest peserta didik.

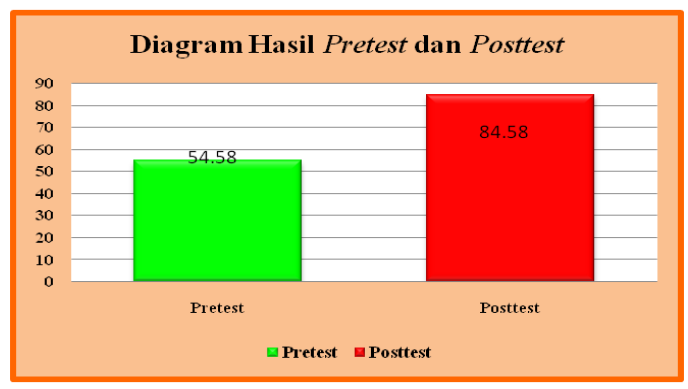

Gambar 4. Diagram Hasil Pretest dan Posttest Peserta Didik

Berdasarkan adanya pretest dan posttest terlihat adanya kenaikan nilai sebelum dan sesudah penggunaan media. 
5. Hasil respon Guru

Hasil perolehan nilai guru pada saat uji coba yaitu 97,36 termasuk dalam kategori sangat baik, sehingga produk pengembangan media pembelajaran tangga pintar layak digunakan dalam proses pembelajaran. Proses menghitung nilai sebagai berikut.

$$
\begin{aligned}
x & =\frac{\text { jumlah nilai yang diperoleh }}{\text { jumlah nilai maksimum }} \times 100 \\
& =\frac{74}{76} \times 100 \\
& =97,36
\end{aligned}
$$

\section{B. Analisis Data}

\section{Analisis Data Kualitatif}

Pertama yaitu analisis data ahli media. Adapun komentar atau saran yang telah diberikan oleh ahli media antaralain, tulisan huruf dan angka lebih diperbesar, pada media ditambahkan animasi yang menarik serta berkaitan dengan materi. pemilihan warna lebih disesuaikan, pengembangan media pembelajaran tangga pintar materi penjumlahan dan pengurangan telah selesai dikembangkan.

Kedua analisis data ahli materi. Analisis ini untuk mengetahui saran ataupun komentar berkaitan dengan materi dan media yang dikembangkan. Adapun komentar atau saran yang diberikan oleh ahli materi antara lain materi perlu disajikan dari tingkat kesukaran yang rendah, sedang, sampai sulit, ukuran huruf dan angka diperbesar dalam draf materi, sajikan soal sesuai jumlah yang cukup.

Ketiga analisis data ahli pembelajaran. Analisis ini diperlukan guna memberikan kesesuaian antara media dan pembelajaran yang berkaitan dengan media yang dikembangkan. Adapun komentar dan saran tersebut yaitu indikator diperbaiki sesuai saran, pemilihan karakter pencapaian disesuakan dengan pembelajaran, bagian apersepsi dibahasakan rinci, materi disesuaikan dengan karakteristik peserta didik.

Keempat data respon guru dan peserta didik. Adapun komentar ataupun saran yang diberikan oleh guru yaitu media yang digunakan bagus, menarik membuat peserta didik ikut aktif dalam pembelajaran, sesuai untuk belajar mengenal simbol angka dan berhitung. Respon dar peserta didik, medianya bagus, senang belajar menggunakan media tangga pintar, gambarnya lucu.

2. Analisis Data Kuantitatif

Berdasarkan hasil perhitungan nilai yang telah dilakukan enggunakan rumus, maka hasil penilaian masing-masing penilai dapat dilihat di tabel berikut.

\begin{tabular}{|c|c|c|c|}
\hline No & Penilaian & Nilai & Kategori \\
\hline 1 & Ahli Media & 78,12 & Baik \\
\hline 2 & Ahli Materi & 88,75 & $\begin{array}{l}\text { Sangat } \\
\text { Baik }\end{array}$ \\
\hline 3 & $\begin{array}{l}\text { Ahli } \\
\text { Pembelajaran }\end{array}$ & 78,94 & Baik \\
\hline 4 & Respon Guru & 97,36 & $\begin{array}{l}\text { Sangat } \\
\text { Baik }\end{array}$ \\
\hline 5 & $\begin{array}{l}\text { Respon } \\
\text { peserta didik } \\
\text { uji coba I }\end{array}$ & 78,07 & Baik \\
\hline 6 & $\begin{array}{l}\text { Respon } \\
\text { peserta didik } \\
\text { uji coba II }\end{array}$ & 89,92 & $\begin{array}{l}\text { Sangat } \\
\text { Baik }\end{array}$ \\
\hline & Jumlah & 511,16 & \\
\hline & Rata-Rata & 85,19 & $\begin{array}{l}\text { Sangat } \\
\text { Baik }\end{array}$ \\
\hline
\end{tabular}

Tabel 6. Hasil Akumulasi Kelayakan Media Tangga Pintar

Pembahasan

Proses pengembangan media pembelajaran tangga pintar dilakukan dari tahap ke tahap dan mengikuti langkahlangkah pengembangan sehingga menghasilkan media yang layak untuk digunakan. Langkah pengembangan ini didasarkan pada model pengembangan 
ADDIE (Sugiyono, 2016). Berikut ini merupakan tahapan-tahapan yang dilakukan 1) Analysis, 2) Design, 3) Development, 4) Implementation dan Evaluation.

Setelah tahapan tersebut diselesaikan, selanjutnya yaitu menghitung hasil keseluruhan penilaian media. Berdasarkan validasi media ini memperoleh nilai dari ahli media 78,12 masuk dalam kategori "baik", penilaian ahli materi 88,75 dalam kategori "sangat baik", ahli pembelajaran 78,94 kategori "baik". Penilaian berdasarkan hasil dari uji coba I dan uji coba II, mendapatkan nilai angket respon peserta didik rata-rata 83,99 yang masuk pada kategori "sangat baik". Pada penilaian oleh guru berdasarkan angket yang diberikan mendapatkan nilai 97,36 yang masuk pada kategori "sangat baik". Hasil pretest menunjukan nilai rata-rata 54,58 dan hasil posttest mendapatkan nilai rata-rata 84,58 , perubahan rata-rata nilai tersebut menunjukkan adanya kenaikan setelah menggunakan media pada saat pembelajaran.

Berdasarkan hasil tersebut maka dapat dikatakan bahwa media yang dikembangkan layak untuk digunakan dalam kegiatan pembelajaran pada materi penjumlahan dan pengurangan kelas I sekolah dasar. Selaras dengan pendapat yang dikemukanan oleh Eriksson dan Curl (Indriana, 2011) bahwasannya media yang baik untuk digunakan memiliki karakteristik kandungan media yang menarik bagi peserta didik, isi yang sesuai, media yang disesuaikan dengan karak-teristik peserta didik, serta sesuai dengan tujuan ataupun materi yang diajarkan.

Hal tersebut merupakan pedoman yang digunakan dalam pengembangan media pembelajaran tangga pintar, dimana media tangga pintar dikembangkan sesuai karakteristik- karakteristik tersebut.

Produk akhir media pembelajaran tangga pintar materi penjumlahan dan pengurangan terdiri atas beberapa bagian. Berikut disajikan produk akhir masingmasing bagian media pembelajaran tangga pintar materi penjumlahan dan pengurangan.
Bagian papan media tangga pintar, terdiri dari anak tangga yang berjumlah sepuluh anak tangga, dengan setiap anak tangga memiliki simbol angka. Bagian sisi kanan dan kiri tangga terdapat gambargambar yang berkaitan dengan materi.

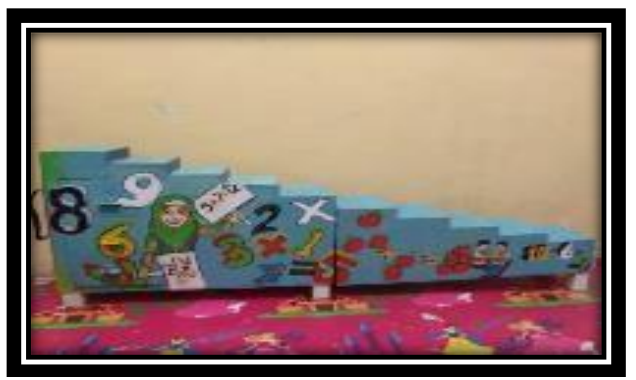

Gambar 5. Bagian Papan Media

Bagian stik bergambar ini merupakan bagian dari media tangga pintar yang digunakan sebagai media untuk melakukan penjumlahan dan pengurangan. Terdapat tiga macam bentuk stik bergambar antara lain jeruk, stroberi, dan apel. Masing-masing stik terdiri dari 20 stik bergambar.

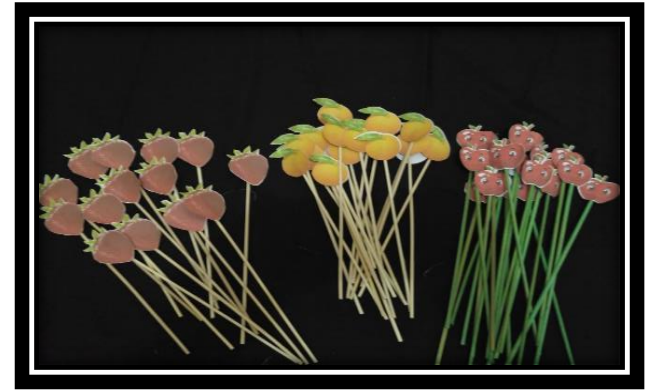

Gambar 6. Bagian Stik Bergambar pada Media

Bagian laci media, bagian ini digunakan untuk menyipan soal maupun stik bergambar agar tersimpan rapi.

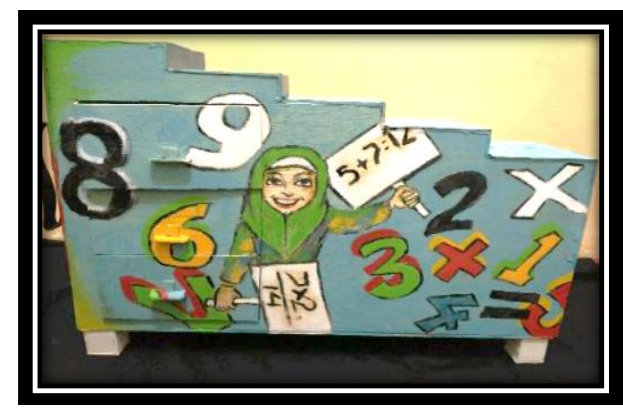

Gambar 7. Bagian Laci Media 


\section{PENUTUP}

Berdasarkan hasil penelitian dan pengembangan media tangga pintar penjumlahan dan pengurangan kelas I sekolah dasar, maka dapat disimpulkan bahwa. Pengembangan media pembelajaran tangga pintar pada mata pelajaran matematika materi penjumlahan dan pengurangan (bilangan 11 sampai 20 dan lambangnya) kelas I sekolah dasar menggunakan model pengembangan ADDIE (Analysis, Design, Development, Implementatiton, Evaluation); Media pembelajaran media pembelajaran tangga pintar pada mata pelajaranmatematika materi penjumlahan dan pengurangan (bilangan 11 sampai 20 dan lambangnya) kelas I sekolah dasar, dinyatakan "layak" untuk digunakan sebagai media pembelajaran matematika. Hal ini berdasarkan penilaian dari ahli media, ahli materi, ahli pembelajaran, guru, dan peserta didik, sebagai berikut:

Penilaian oleh ahli media mendapat nilai 78, 12 dengan kategori baik; Penilaian oleh ahli materi mendapat nilai 88,75 dengan kategori sangat baik; Penilaian oleh ahli pembelajaran mendapat nilai 78, 94 dengan kategori sangat baik. Hasil uji coba I dan uji oba II yang dilakukan di SD Muhammadiyah Mantaran. Penilaian angket respon peserta didik rata-rata nilai 83, 99, pretest 54,58 posttest 84, 58 termasuk dalam kategori sangat baik. Sedangkan, pada penilaian angket guru adalah 97.36 termasuk dalam kategori sangat baik.

\section{DAFTAR PUSTAKA}

Arikunto, S. (2011). Dasar-Dasar Evaluasi Pendidikan (Edisi Revisi). Jakarta: Bumi Aksara.

Arsyad, A. (2015). Media Pembelajaran. Jakarta: PT Raja Grafindo Persada.

Hayati, P. N., \& Rahmawati, I. (2017). Pengaruh Media Tangsapan Terhadap Hasil Belajar Pada Materi Pengukuran Panjang Siswa Kelas 3 Tema 6 Subtema 1 SDN Babatan I Surabaya. JPGSG, 05(02). Retrieved from http://jurnalmahasiswa.unesa.ac.id

Heruman. (2010). Model Pembelajaran Matematika di Sekolah Dasar. Bandung: Remaja Rosdakarya.

Indriana, D. (2011). Ragam Alat Bantu Media Pembelajaran. Yogyakarta: DIVA Press.

Jonkenedi. (2017). Penggunaan Media Tiga Dimensi untuk Meningkatkan Keaktifan Siswa dalam Pelajaran IPA. Jurnal Pendidikan Guru Sekolah Dasar Edisi 6 Tahun Ke-6. Retrieved from http://journal.student.uny.ac.id/ojs/in dex.php/pgsd/article/viewFile/7081/6 775

Nurseto, T. (2011). Membuat Media Pembelajaran yang Menarik. Jurnal Ekonomi \& Pendidikan, 8(1). Retrieved from http://journal.uny.ac.id

Santri, F. S. (2016). Pembelajaran Matematika Pendidikan Guru SD/ MI. Yogyakarta: MATEMATIKA.

Sugiyono. (2015). Metode Penelitian Pendidikan: Pendekatan Kuantitatif, Kualitatif, dan R\&D. Bandung: Alfabeta.

Sugiyono. (2016). Metode Penelitian \& Pengembangan Research and Development. Bandung: Alfabeta.

Susanto, A. (2013). Teori Belajar \& Pembelajaran di Sekolah Dasar. Jakarta: Prenadamedia Group.

Yuniawantika. (2016). Pembelajaran Matematika di SD Menggunakan Pendekatan Matematika Realistika Indonesia (PMRI). Jurnal Kajian Teori Dan Praktik Pendidikan, (1). Retrieved from http://journal.um.ac.id/. 